\title{
A Study on the Job Satisfaction of Physical Education Teachers According to Different Variables
}

\author{
Deniz Ozge Yuceloglu Keskin ${ }^{1}$ \\ Levent Bayram²
}

1.2Ondokuz Mayzs University Tasar Dogu, Faculty of Sport Sciences, Turkey. Email:ozge vuceloolu@hotmanl com Tel-90362 3121919/565s

Email: levent.bavram@omu.edu.tr Tel: +903623121919/5639

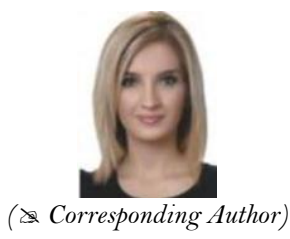

\begin{abstract}
The purpose of the study is to determine the job satisfaction levels of physical education teachers according to the variables of gender, seniority, marital status, grade and status of education. The study was conducted on a total of 103 physical education and sports teachers, 40 females and 63 males, with an average age of 40.01 \pm 6.65 , working at schools in different cities (Samsun, Ordu, Adana and Istanbul) in Turkey in 2019-2020 academic year. The data of the study were collected using demographic information form containing personal information and Minnesota Job Satisfaction Questionnaire. T-test and Mann Whitney U test were used during the evaluation of the data and one-way variance analysis (Anova) and Kruskal Wallis test were performed on items where variables were examined in multiple groups. It was concluded that the teachers participated in the study had high job satisfaction levels; no statistically significant difference was observed in terms of gender, seniority, marital status, grade of education and job status variables $(p>0.05)$. That they share the common feelings and excitement intensely in the competitions attended by the students they have prepared as athletes and that the successful results obtained in these activities are appreciated and congratulated can be interpreted as factors increasing their commitment to work and the pleasure they receive from work.
\end{abstract}

Keywords: Job satisfaction, Physical education teacher, School

Citation | Deniz Ozge Yuceloglu Keskin; Levent Bayram (2020). A Study on the Job Satisfaction of Physical Education Teachers According to Different Variables. Asian Journal of Education and Training, 6(1): 105-109.

History:

Received: 22 November 2019

Revised: 7 January 2019

Accepted: 10 February 2020

Published: 2 March 2020

Licensed: This work is licensed under a Creative Commons

Attribution 3.0 License (c)

Publisher: Asian Online Journal Publishing Group
Acknowledgement: Both authors contributed to the conception and design of the study.

Funding: This study received no specific financial support

Competing Interests: The authors declare that they have no conflict of interests.

Transparency: The authors confirm that the manuscript is an honest, accurate, and transparent account of the study was reported; that no vital features of the study have been omitted; and that any discrepancies from the study as planned have been explained.

Ethical: This study follows all ethical practices during writing.

\section{Contents}

1. Introduction

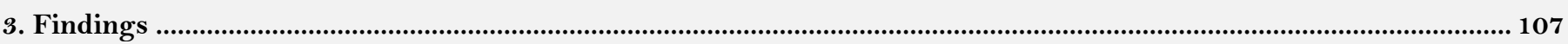

4. Discussion...

References. 


\section{Contribution of this paper to the literature}

This study contributes to the existing literature by determining the job satisfaction levels of physical education teachers according to the variables of gender, seniority, marital status, grade and status of education.

\section{Introduction}

The active life of today is full of effects that are challenging for individuals in many respects, that make them feel under pressure and make it difficult for them to live their lives in a balanced way.

Working and having a job have an important place in human life. A job enables individuals to maintain their lives by creating an opportunity for them to meet their social, financial and psychological needs. Individuals create economic value in the jobs, generate an income in return and meet the needs of them and their families. In addition, a job has social functions such as determining the social status of individuals, creating a sense of being beneficial to the society, enabling meeting with other people and establishing new relationships; and psychological functions such as the pride of having a job and being able to produce, the excitement of starting a job, the feeling of being successful, loving one's job and doing a meaningful act (Çakır, 2001).

Besides providing work-related experiences to the employees, work life also causes accumulation of various emotions faced in each working day. As a result of these experiences, the mental and emotional attitude of the person towards the job is formed. In the event that there are negative accumulations towards the job, unhappy employees who are not satisfied with their job and workplace appear. What is desired and aimed in reality, on the other hand, is that the employees are satisfied with the job they do and the conditions related to the job, and eventually reach a job-related satisfaction (Eğinli, 2009). Job satisfaction or dissatisfaction expresses the internal evaluations of the employees as an outcome of their feelings, thoughts and behaviors towards their jobs, workplaces or colleagues; a general attitude towards their jobs (Solmuş, 2004). There are different factors affecting job satisfaction. It is stated that individual factors such as age, gender, education level, status in the workplace, duration of service and personality structure; and organizational factors such as job and its nature, payment, opportunities of development and promotion, and the physical conditions of the workplace affect the level of satisfaction (Aksoy \& Polat, 2013).

Job dissatisfaction has significant consequences for both employees and organizations. Employees with high job satisfaction endeavor to fulfill their duties in the best way beyond the jobs required by their position at work. However, the decreases in job satisfaction are generally seen to be associated with subjective emotions such as uneasiness, tension, anger, anxiety, depression, and fatigue, and physiological problems such as increase in colds, allergic reactions, gastrointestinal diseases, and substance use when combined with negative life events, daily troubles and personality traits of the individuals. The reflection of these problems on professional life is revealed as psychological withdrawal (dreaming of various things during working hours, etc.), physical withdrawal (going out without permission, shirking from duties, leaving work early-arriving late, taking sick leaves frequently, or long tea breaks, etc.), decrease in efficiency, decrease in concentration, increase in the number of mistakes, decrease in tolerance, insensitivity, conflicts in interpersonal relations, and even behaviors such as aggression (Batıgün \& Şahin, 2006).

It is generally accepted that teachers experience more than the average stress experienced by people working in other professions. Because there are problems in education and training services such as student-teacher, schoolfamily conflicts; disciplinary problems of the students; overcrowded classes and poor physical conditions; too many bureaucratic works; low salaries; difficulties in promotion; criticism of the society; low support from the society; pressures of social and political forces on educational institutions; inadequate rewarding and participation in the decision processes in institutions, and so on. These problems lead to emergence of stress, anxiety and burnout; and are reflected in the educational environment, students, families and the whole society by causing results such as low work performance, desire to quit the job, and even deterioration of physical and mental health (Celep, 2003).

The main factor contributing to the job satisfaction of the teachers is that they work with children. That the teachers develop warm, sincere and personal relationships with students, that teaching is an intellectual and challenging job, and that the teaching profession provides autonomy and independence contribute to satisfaction (Shann, 1998). Other sources of job satisfaction for teachers include; relationships with students, relationships with teachers, relationships with senior managers, the opportunity to implement their own ideas, holidays, financial security, salary payments, working conditions, realizing personal interests, working hours, the nature of the job, the possibility of promotion, supervision, organization and management, occupational safety, personality and appreciation (Vural, 2004).

According to the results of researches conducted on job satisfaction of teachers, pressure and stress are felt by the teachers who interact with students all day and who try to meet the learning needs of students; their motivation decreases due to the factors such as not being able to improve themselves in terms of knowledge, skills and professional competence, and not meeting their professional requirements; and as a result of these job dissatisfaction occurs (Akçamete, Kamer, \& Sucuoğlu, 2001).

In this context, it is aimed to determine the job satisfaction levels of physical education teachers working in schools according to different variables.

Answers to the following questions are sought in line with this general purpose:

1. Do the job satisfaction and subscales of the physical education and sports teachers differ significantly according to gender variable?

2. Do the job satisfaction and subscales of the physical education and sports teachers differ significantly according to marital status variable?

3. Do the job satisfaction and subscales of the physical education and sports teachers differ significantly according to seniority variable?

4. Do the job satisfaction and subscales of the physical education and sports teachers differ significantly according to job status variable? 
5. Do the job satisfaction and subscales of the physical education and sports teachers differ significantly according to the school type variable?

\section{Method}

\subsection{Sample and Procedure}

The study was applied on a total of 103 physical education and sports teachers - 40 females and 63 males working at schools in different cities in Turkey (Samsun, Ordu, Adana and Istanbul) in 2019-2020 academic year, whose average age was $40.01 \pm 6.65$. The study was conducted with the quantitative method, and screening and correlational screening models were used. The data of the study were collected by use of demographic information form containing personal information and Minnesota Job Satisfaction Questionnaire.

\subsection{Measures}

Minnesota Job Satisfaction Questionnaire (MSQ) The first scale used in the study is the Minnesota Job Satisfaction Questionnaire consisting of twenty questions that was developed by Weiss, Dawis, England, and Lofquist (1967) in order to measure job satisfaction. It was adapted to Turkish by Baycan in 1985 and its validity and reliability studies were conducted. Minnesota Job Satisfaction Questionnaire is a five-point Likert type scale scored between $1-5$. In the questionnaire the points are evaluated as: very dissatisfied; 1 point, dissatisfied; 2 points, undecided; 3 points, satisfied; 4 points, and very satisfied; 5 points. There is no reverse question in the questionnaire. The highest score that can be obtained from the questionnaire is 100 , the lowest score is 20 , and 60 points corresponding to the middle point represent neutral satisfaction. When the scores approach to 20, it indicates that the level of satisfaction decreases, and when they approach to 100, it means the increase of satisfaction. Minnesota Job Satisfaction Questionnaire consists of 20 items and 3 subscales with features determining the level of intrinsic, extrinsic and general satisfaction.

\subsection{Data Analysis}

The data of the study were obtained by using "SPSS 22.0" software. In the evaluation of demographic information about physical education teachers, frequency (f) and percentage (\%) were calculated and given in tables. During the evaluation of the data, the T-test and Mann Whitney $U$ test were used for independent variables in paired groups, and one-way variance analysis (Anova) and Kruskal Wallis test were performed on items where variables were examined in multiple groups to determine whether a significant difference existed between the groups or not. The level of significance was accepted to be $(p<.05)$ for the study.

\section{Findings}

Table-1. T-test results related to the job satisfaction perceptions of the teachers according to gender variable.

\begin{tabular}{|c|c|c|c|c|c|c|c|c|}
\hline Subscales & Gender & $\mathbf{N}$ & Aver. & Sd. & Median & Min. & Max. & p \\
\hline \multirow{2}{*}{ Intrinsic Satisfaction } & Female & 40 & 48.38 & 6.72 & 48 & 25 & 59 & \multirow{2}{*}{.977} \\
\hline & Male & 63 & 48.41 & 6.25 & 48 & 29 & 60 & \\
\hline \multirow{2}{*}{ Extrinsic Satisfaction } & Female & 40 & 28.40 & 4.42 & 28 & 19 & 38 & \multirow{2}{*}{.148} \\
\hline & Male & 63 & 26.90 & 5.96 & 28 & 13 & 39 & \\
\hline \multirow{2}{*}{ General Satisfaction } & Female & 40 & 76.77 & 10.35 & 78 & 44 & 97 & \multirow{2}{*}{.514} \\
\hline & Male & 63 & 75.31 & 11.38 & 76 & 42 & 99 & \\
\hline
\end{tabular}

$$
\text { Note: } \mathrm{p}>0.05 \text {. }
$$

When Table 1 is analyzed, no significant difference is seen in the job satisfaction perceptions of the teachers according to their genders in the subscales of intrinsic and extrinsic satisfaction and in the general job satisfaction $(\mathrm{p}>0.05)$.

Table-2. T-test results related to the job satisfaction perceptions of the teachers according to marital status variable.

\begin{tabular}{|c|c|c|c|c|c|c|c|c|}
\hline Subscales & Marital status & $\mathbf{N}$ & Aver. & Sd. & Median & Min. & Max. & $\bar{p}$ \\
\hline \multirow{3}{*}{ Intrinsic Satisfaction } & Single & 14 & 48,07 & 8,38 & 49,5 & 25 & 59 & \multirow{3}{*}{.529} \\
\hline & Married & 84 & 48,64 & 5,99 & 48 & 29 & 60 & \\
\hline & Divorced & 5 & 45.20 & 7.60 & 45 & 36 & 55 & \\
\hline \multirow{3}{*}{ Extrinsic Satisfaction } & Single & 14 & 28,86 & 5,80 & 28 & 19 & 38 & \multirow{3}{*}{.581} \\
\hline & Married & 84 & 27.34 & 5,48 & 28 & 13 & 39 & \\
\hline & Divorced & 5 & 26 & 3,46 & 28 & 20 & 28 & \\
\hline \multirow{3}{*}{ Job Satisfaction (Total) } & Single & 14 & 76.93 & 13.09 & 74,50 & 44 & 97 & \multirow{3}{*}{.597} \\
\hline & Married & 84 & 75.99 & 10,69 & 78 & 42 & 99 & \\
\hline & Divorced & 5 & 71.20 & 10.33 & 71 & 56 & 83 & \\
\hline
\end{tabular}

Note: $\mathrm{p}>0.05$.

In Table 2 , there is no statistically significant difference in the intrinsic and extrinsic satisfaction subscales and general job satisfaction according to the marital status of the teachers $(\mathrm{p}>0.05)$.

When the results of the t-test related to the job satisfaction perceptions of the teachers according to seniority variable in Table 3 are evaluated, no statistically significant difference is determined in the intrinsic and extrinsic satisfaction subscales and general job satisfaction $(p>0.05)$. 
Table-3.T-test results related to the job satisfaction perceptions of the teachers according to seniority variable.

\begin{tabular}{|c|c|c|c|c|c|c|c|c|}
\hline Subscales & Seniority & $\mathbf{N}$ & Aver. & Sd. & Median & Min. & Max. & p \\
\hline \multirow{5}{*}{ Intrinsic Satisfaction } & $1-5$ years & 11 & 45,091 & 9,481 & 45 & 25 & 60 & \multirow{5}{*}{.354} \\
\hline & $6-10$ years & 23 & 48,13 & 8,019 & 49 & 29 & 60 & \\
\hline & $11-15$ years & 24 & 49.96 & 4,658 & 50 & 42 & 60 & \\
\hline & 16-20 years & 19 & 48,32 & 5,355 & 48 & 36 & 60 & \\
\hline & 20 and over & 26 & 48,65 & 5,623 & 48 & 16 & 36 & \\
\hline \multirow{5}{*}{ Extrinsic Satisfaction } & $1-5$ years & 11 & 27,73 & 7,143 & 28 & 16 & 39 & \multirow{5}{*}{.547} \\
\hline & $6-10$ years & 23 & 26,57 & 5,534 & 27 & 13 & 34 & \\
\hline & 11-15 years & 24 & 28.67 & 4,659 & 29 & 19 & 39 & \\
\hline & 16-20 years & 19 & 28,32 & 5,012 & 30 & 17 & 36 & \\
\hline & 20 and over & 26 & 26.50 & 5,623 & 27 & 16 & 36 & \\
\hline \multirow{5}{*}{ Job Satisfaction (Total) } & $1-5$ years & 11 & 72,82 & 15,432 & 72 & 44 & 99 & \multirow{5}{*}{.594} \\
\hline & $6-10$ years & 23 & 74,70 & 13,275 & 74 & 42 & 94 & \\
\hline & 11-15 years & 24 & 78,63 & 8,287 & 79 & 61 & 99 & \\
\hline & 16-20 years & 19 & 76,63 & 9,209 & 76 & 53 & 90 & \\
\hline & 20 and over & 26 & 75,15 & 10.110 & 77 & 53 & 92 & \\
\hline
\end{tabular}

Note: $\mathrm{p}>0.05$

Table-4. T-test results related to the job satisfaction perceptions of the teachers according to job status variable.

\begin{tabular}{l|c|c|c|c|c|c|c|c}
\hline Subscales & Job status & $\mathbf{N}$ & Aver. & Sd. & Median & Min. & Max. & P \\
\hline \multirow{2}{*}{ Intrinsic Satisfaction } & Public & 90 & 48,77 & 5.71 & 48 & 29 & 60 & \multirow{2}{*}{.267} \\
\cline { 2 - 10 } & Private & 13 & 45.85 & 5,72 & 46 & 25 & 60 & \\
\hline \multirow{2}{*}{ Extrinsic Satisfaction } & Public & 90 & 27.42 & 5.15 & 28 & 13 & 39 & \multirow{2}{*}{.687} \\
\cline { 2 - 10 } & Private & 13 & 27.92 & 7.39 & 28 & 16 & 38 & \\
\hline \multirow{2}{*}{ Job Satisfaction (Total) } & Public & 90 & 76.19 & 10.011 & 77.5 & 42 & 99 & \multirow{2}{*}{.615} \\
\cline { 2 - 8 } & Private & 13 & 73,77 & 16,53 & 74 & 44 & 97 & \\
\hline
\end{tabular}

When the results of the t-test for the job satisfaction perceptions of the teachers according to job status variable in Table 4 are examined, no statistically significant difference is observed in the intrinsic and extrinsic job satisfaction subscales and general job satisfaction $(\mathrm{p}>0.05)$.

\begin{tabular}{l|c|c|c|c|c|c|c|c}
\multicolumn{1}{c|}{ Table-5. T-test results related to the job satisfaction perceptions of the teachers according to grade of education variable. } \\
\hline Subscales & Grade of Education & $\mathbf{N}$ & Aver. & Sd. & Median & Min. & Max. & p \\
\hline \multirow{2}{*}{ Intrinsic Satisfaction } & Secondary School & 66 & 48.51 & 7.04 & 48 & 25 & 60 & \multirow{2}{*}{0.486} \\
\cline { 2 - 10 } & High School & 37 & 48.19 & 5,16 & 48 & 37 & 60 & \\
\hline \multirow{2}{*}{ Extrinsic Satisfaction } & Secondary School & 66 & 27.62 & 5.86 & 28 & 13 & 39 & \multirow{2}{*}{0.737} \\
\cline { 2 - 10 } & High School & 37 & 27.24 & 4.66 & 28 & 16 & 38 & \\
\hline \multirow{2}{*}{ Job Satisfaction (Total) } & Secondary School & 66 & 76.13 & 12.09 & 78 & 42 & 99 & \multirow{2}{*}{0.756} \\
\cline { 2 - 9 } & High School & 37 & 75.43 & 8.74 & 76 & 57 & 97 & \\
\hline
\end{tabular}

Note: $\mathrm{p}>0.05$.

No statistically significant difference is found according to the grade of education where the teachers participated into the study work in Table 5 , in the total of job satisfaction scale ( $p>0.05)$ and in the subscales of intrinsic job satisfaction $(\mathrm{p}>0.05)$ and extrinsic satisfaction $(\mathrm{p}>0.05)$.

\section{Discussion}

This study was conducted on a total of 103 physical education and sports teachers, 40 females and 63 males, with an average age of $40.01 \pm 6.65$, working at schools in different cities of Turkey. The purpose of the study was to determine the job satisfaction levels according to the variables of gender, seniority, marital status, grade of education, and job status.

In the study, it was concluded that there was no significant difference in terms of general job satisfaction and subscales between genders for physical education teachers. There are other researchers in the literature who concluded that job satisfaction levels of the teachers did not change according to gender (Tasdan \& Tiryaki, 2008; Yllmaz, 2012). On the other hand, there are also results revealing that male teachers had higher job satisfaction in some studies and in some others female teachers were found to have higher job satisfaction levels. In the study conducted by Sahin (1999) it was determined that the job satisfaction levels of female teachers in primary education were higher than the job satisfaction level of male teachers. In the study carried out by Kinalı (2000) the job satisfaction levels of male advisory teachers working in public and private schools were found to be higher than the job satisfaction levels of female advisory teachers.

In this study it was concluded that there was no significant difference in terms of general job satisfaction and subscales according to marital status variable among physical education teachers. In parallel with this study, Sahin. and Dursun (2009) did not observe a statistically significant difference among the job satisfaction levels of preschool teachers according to their marital status ( $\mathrm{p}>0.05)$.

No significant difference was determined in the study in terms of working in public or private school in the general job satisfaction and subscales for physical education teachers. In parallel with the results of this study, Dilsiz (2006) concluded that there was no significant difference between school types in terms of job satisfaction. However, in the study by Tasdan and Tiryaki (2008) on the contrary to this study, the job satisfaction level of private primary school teachers was found to be higher than that of public school teachers in the entire questionnaire and subscales.

In this study, no significant difference was found among the physical education teachers working at secondary or high school grades regarding the general job satisfaction and any of the subscales $(p>0.05)$. In parallel with this 
study, according to the research conducted by Bilgili (2019) there was no significant difference between the job satisfaction levels of physical education teachers working at secondary schools and high schools (Bilgili, 2019).

It was understood, in this study, that there was no significant difference in the general job satisfaction and subscales among physical education teachers according to the seniority variable. Unlike the findings in this study, in the study carried out by Güner (2007) a positive correlation was found between the time of working and job satisfaction $(\mathrm{p}<0.05)$. Mete $(2006)$ analyzed the job satisfaction levels of classroom teachers and branch teachers working in primary schools and determined that there was a significant difference between job satisfaction levels and seniority of the teachers. It was found out that the job satisfaction of teachers working for 16 years or more were higher.

In the event that scores obtained from the questionnaire in the study are closer to 20, the satisfaction level decreases, and if the scores are closer to 100, it means that the level of satisfaction increases. In light of this information, it can be concluded that the job satisfaction levels of the teachers participated in the study are high.

As a result, another factor distinguishing physical education teachers from other teachers in schools is that they interact more with the students. That they share the common feelings and excitement intensely in the competitions attended by the students they have prepared as athletes and that the successful results obtained in these activities are appreciated and congratulated can be interpreted as factors increasing their commitment to work and the pleasure they receive from their job.

\section{References}

Akçamete, G., Kamer, S., \& Sucuoğlu, B. (2001). Burnout, job satisfaction and personality in teachers. Ankara: Nobel Publishing Distribution.

Aksoy, N., \& Polat, C. (2013). Job satisfaction and affecting factors of surgical unit nurses of three different hospitals in a province in mediterranean region. The Koç University Journal of Education and Research in Nursing, 10(2), 45-53.

Batıgün, A. D., \& Şahin, N. H. (2006). Two scales for work stress and health psychology research: A-Type personality and job satisfaction. Turkish Journal of Psychiatry, 17(1), 32-25.

Bilgili, C. (2019). Examination of job satisfaction and professional burnout levels of physical education teachers (Case of Van Province). Master Thesis. Van Yüzüncü Yll University. Education Sciences Institute, Physical Education and Sport Department, Van. Turkey.

Çakır, Ö. (2001). The phenomenon of loyalty and affecting factors (Vol. 29). Ankara: Seçkin Publishing.

Celep, C. (2003). Professional burnout of teachers in secondary education. Paper presented at the Contemporary Approaches to High School Education in 2000 s Symposium, Istanbul Kültür University. Istanbul.

Dilsiz, B. (2006). Multivariate statistical analysis of the evaluation of burnout and job satisfaction levels of teachers working in secondary schools in Konya by region. Ph.D. Thesis, Selcuk University Institute of Science.

Eğinli, A. T. (2009). Job satisfaction in employees: A research on job satisfaction of public and private sector employees. Atatürk University Journal of Economics and Administrative Sciences, 23(3), 35-52.

Güner, A. R. (2007). Modeling the relationships between organizational commitment, job commitment and job satisfaction in health care services. Master Thesis. Akdeniz University, Social Sciences Institute, Antalya. Turkey.

Kınall, G. (2000). Job satisfaction of counselors in public and private schools. Master Thesis. Istanbul University. Social Sciences Institute. Istanbul. Turkey.

Mete, C. (2006). Investigation of the relationship between personality traits and job satisfaction levels of teachers working in primary schools. Master Thesis, Yeditepe University, Social Sciences Institute. Istanbul. Turkey.

Sahin, İ. (1999). Job satisfaction levels of teachers in primary schools. Master Thesis, Dokuz Eylül University, Education Sciences Institute. Izmir. Turkey.

Sahin., H., \& Dursun, A. (2009). Job satisfaction of preschool teachers: The case of Burdur. Mehmet Akif Ersoy University Journal of Education Faculty, 18, 160-174.

Shann, M. H. (1998). Professional commitment and satisfaction among teachers in urban middle schools. The Journal of Educational Research, 92(2), 67-73.

Solmuş, T. (2004). Emotions and interpersonal relations in business life, human resources management through psychology window. Istanbul: Beta Broadcasts.

Tasdan, M., \& Tiryaki, E. (2008). Comparison of the level of job satisfaction between at private and state primary school teachers. Education and Science, 33(147), 54-70.

Vural, B. (2004). Yetkin-Ideal-Vizyoner ogretmen. Istanbul: Hayat Publications.

Weiss, D. J., Dawis, R. V., England, G. W., \& Lofquist, L. H. (1967). Manual for the minnesota satisfaction questionnaire. Minneapolis, MN: University of Minnesota Industrial Relations Center.

Yllmaz, K. (2012). The relationship between primary school teachers' job satisfaction levels and organizational citizenship behaviors. Anadolu Journal of Educational Sciences International, 2(2), 1-15. 